
389-394.

\title{
Row spacing and pruning regimes on organically grown cherry tomato
}

\author{
Vlamir F de Azevedo; Antônio Carlos de S Abboud; Margarida Goréte F do Carmo ${ }^{2}$ \\ UFRRJ- Instituto de Agronomia, Depto. Fitotecnia, C. Postal 74583, 23890-000 Rio de Janeiro-RJ; ${ }^{2}$ Autor correspondente; gorete@ufrrj. \\ br
}

\begin{abstract}
The effects of branch number and plant densities on organically grown cherry tomato yield and fruit quality were studied. Labor costs for pruning were also assessed. The essay was conducted at the experimental fields of the Universidade Federal Rural do Rio de Janeiro, Brazil, from September 2004 to January 2005. A factorial design was used combining three row spacings $(0.4,0.6$ and 0.8 $\mathrm{m}$ ), two cherry tomato cultivars (hybrid 'Super-Sweet' and a local self pollinated 'Perinha') and three pruning regimes (free growth, one branch per plant and two branches per plant). The row spacing treatment of $0.6 \times 1.5 \mathrm{~m}$ resulted in lower number of fruits when compared to the $0.4 \times 1.5 \mathrm{~m}$ treatment, however, producing fruits with higher individual average mass, which resulted in similar final yield. These yields were higher than the $0.8 \mathrm{~m}$ treatment. Yield increases due to the higher number of plants per area were mostly due to the increase of fruit number, which compensated for the decrease of fruit size and mass. The 'free growth' treatment yielded similarly to the two branches per plant treatment. The labor costs were lower under 'free growth' due to the absence of pruning. Both cultivars responded similarly to plant population and pruning regimes.
\end{abstract}

Keywords: Lycopersicon esculentum, number of branches, labor costs.

\section{RESUMO}

Espaçamento e sistema de condução de tomate cereja em cultivo orgânico

Com o objetivo de se avaliar o efeito do manejo e da densidade de plantio na produtividade de frutos e no custo com mão de obra em sistema orgânico de produção de tomate cereja, foi realizado um experimento no Departamento de Fitotecnia da UFRRJ, SeropédicaRJ, de setembro de 2004 a janeiro de 2005 . Foram avaliados os efeitos da combinação de três sistemas de condução (sem tutoramento e sem limitação do número de hastes por planta; tutoramento com condução de uma haste por planta e, tutoramento com condução de duas hastes por planta), três espaçamentos entre plantas $(0,4 ; 0,6$ e $0,8 \mathrm{~m})$ e duas cultivares de tomate cereja (Perinha Água Branca e Super Sweet). O tratamento com espaçamento de 0,6 x 1,5 m apresentou menor número total de frutos comparado ao tratamento de $0,4 \times 1,5 \mathrm{~m}$, porém frutos com maior massa média, resultando ao final em produtividade equivalente à do tratamento com menor espaçamento. A produtividade destes dois espaçamentos foi significativamente maior do que a do tratamento $0,8 \times 1,5 \mathrm{~m}$. O aumento de produtividade com o aumento da população de plantas deveu-se, principalmente, ao aumento do número total de frutos, tendo compensado a redução do tamanho e massa média dos mesmos, sem afetar a sua qualidade no que diz respeito à sua classificação quanto ao calibre. $\mathrm{O}$ sistema rasteiro apresentou produtividade de frutos comerciais igual à do tratamento onde as plantas foram conduzidas sob tutoramento mantendo-se duas hastes por planta e menor custo de produção devido à não realização das desbrotas e tutoramento. As duas cultivares, em geral, responderam de forma similar às variações de espaçamento e forma de condução.

Palavras-chave: Lycopersicon esculentum, número de hastes, custo de produção.

(Recebido para publicação em 22 de junho de 2009; aceito em 5 de agosto de 2010)

(Received on June 22, 2009; accepted on August 5, 2010)

$\mathrm{T}_{\mathrm{t}}^{\mathrm{h}}$ he tomato plant (Lycopersicon esculentum Mill) presents a great variety of fruits' characteristics, allowing its classification within different commercial groups (Filgueira, 2003). Among them, there is the cherry tomato, which has shown an increasing participation in the market, mainly within organic products. There exist little information on organic tomato management, especially on aspects related to the most adequate management practices, absence of adequate cultivars and, pest or disease management, which justify research to determine better strategies to organically manage cherry tomato crops.

In order to improve the cherry tomato crop performance it is essential to evaluate plant population, pruning regimes and planting times. Plant density is a very limiting factor regarding production of tomato for in natura consumption, once it interferes with

\footnotetext{
This work is part of the first author's dissertation, presented to the UFRRJ plant sciences program to obtain a Master's degree.
} 
yield, fruit quality and phytosanitary status. Ideal plant densities can vary according to the number of branches per plant. This number can be controlled by pruning. Dense planting with large number of branches per plant may result in low total and commercial production of large fruits and a high production of medium and small size fruits (Oliveira et al., 1995), of low or no trade value. It also results in more phytosanitary problems due to moisture accumulation, which facilitate the contamination by fungal and bacterial diseases, and make the pulverization process more difficult (Boff et al., 1992).

Such effect over the fruit size is extremely important for the cultivars which produce large, round and oblong fruits once the market tends to have preference for full grained fruits or with bigger dimension. There is no reference in terms of market preference concerning the cherry tomatoes. For cultivars from the Santa Cruz group, carried out in stakes, the recommended row spacings vary from 1.0 to $1.2 \mathrm{~m}$ with plants 0.3 to $0.7 \mathrm{~m}$ apart (Filgueira, 2003; Carvalho \& Tessarioli Neto, 2005). However, for the cherry tomato group grown under field conditions, there is no reported information on the most adequate spacings. In greenhouse, Alvarenga (2004) suggests spacings of 1.0 to $1.1 \mathrm{~m}$ between rows and 0.5 to 0.7 $\mathrm{m}$ between plants.

Another important aspect to be considered is the pruning regime, and the number of branches and clusters to be pruned. In table tomato production, staking with frequent pruning is a common practice, which means, repeated elimination of lateral sprouts, by pruning one or two branches per plant (Filgueira, 2003; Marim et al., 2005; Wamser et al., 2007). Pruning the plant top can favor light interception, increase photosynthetic activity and, consequently, the yield and fruit quality, even under higher densities (Ho, 1999). Staking also contributes to avoid the plant contact with the soil, increasing ventilation and reducing moisture throughout the crop cycle; it also facilitates other management practices (Lédo et al., 1995; Rughoo \& Govinden, 1999). Such effects are more evident when using vertical staking, once it increases radiation and ventilation over the plants' canopy and reduces the period of foliar wetting and the contamination by disease agents (Santos et al., 1999; Wamser et al., 2008). The positive effects of the vertical staking over the yield, fruit quality and phytosanitary management can be increased by widening plant spacing and reducing the number of branches per plant (Wamser et al, 2008).

The objective of this study was to evaluate the effect of branches number per plant and planting density on the yield, fruit quality and labor cost for organically grown cherry tomato cultivars.

\section{MATERIAL AND METHODS}

The essay was carried out in the experimental fields of the Universidade Federal Rural do Rio de Janeiro, Seropédica, Brazil, from September, 2004 to January, 2005.

Eighteen treatments combining three pruning regimes (free growth without stakes, without a limited number of branches; staked with one branch per plant and staked with two branches per plant); three spacings between the plants $(0.4 ; 0.6$ and $0.8 \mathrm{~m})$ and two cherry tomato cultivars (Super Sweet and Perinha Água Branca) were evaluated. The experimental design consisted of a $3 \times 3 \times 2$ split-split-plot on randomized complete blocks. Three spacings and three pruning forms were assigned on main plots whereas the two tested cultivars were assigned on subplots, with four replicates. On each plot of 6.0 $\mathrm{x} 4.5 \mathrm{~m}$, two subplots of $3.0 \times 4.5 \mathrm{~m}$ were arranged with three rows of plants and spacings of $1.5 \mathrm{~m}$ between them. The evaluations were done in the central plants of each subplot.

The area was plowed after application of $1.5 \mathrm{t} \mathrm{ha}^{-1}$ dolomite limestone as suggested by the results of the soil chemical analyses. The area was then harrowed so that beds could be lifted with approximately $1.2 \mathrm{~m}$ of width and $0.3 \mathrm{~m}$ of height. Beds were used in order to prevent moisture accumulation or flooding, which is very common on the location in the summer. After preparing the holes on the soil, $800 \mathrm{~g}$ of cow manure and $15 \mathrm{~g}$ of thermophosphate per hole were applied. Plantlets which were produced on polystyrene trays in a greenhouse, were transplanted two weeks after emergence. The organic management consisted of applying mulch and drip irrigating, with a twoday watering shift with application of $12.7 \mathrm{~mm}$ water. Manure was applied 56 days after transplanting, by applying $800 \mathrm{~g}$ of cow manure and $80 \mathrm{~g}$ of oven ashes per plant. The plants were staked by using vertical strings. In the treatments at free growth no binding or pruning was done. In the treatments where plants were conducted with one or two branches, the lateral sprouts or prunings were eliminated once a week starting 35 days after the transplant and proceeded for 55 more days, totaling nine prunings. The sprout thinning was performed manually when presenting approximately 1 to $5 \mathrm{~cm}$ of length, leaving only the main branch or the main branch with a first lateral sprout, in the treatments with one or two branches, respectively.

Harvests occurred twice a week, starting 69 days after transplanting when the fruits were ripe. The analyzed variables were number of clusters $\mathrm{m}^{-2}$, fruits per plant $\mathrm{t}^{-1}$ and fruits $\mathrm{m}^{-2}$; total and commercial fruit yield expressed in $\mathrm{kg}$ plant $^{-1}$ and $\mathrm{ha}^{-1}$, and the labor cost used in the pruning expressed in day man $^{-1}$ $\mathrm{ha}^{-1}$. Total yield was determined by the addition of all the fruits obtained throughout the harvests and, the commercial yield by considering only the firm ripe fruits, without any damage (mechanic, physiological or signs and symptoms of plagues and diseases).

The additional labor cost due to pruning was determined by monitoring the time spent for the operation, followed by the calculation man day $\mathrm{ha}^{-1}$ and then calculating the costs in " $\mathrm{R} \$$ ". The price established for an eight hour day shift was "R\$20.00" and, in order to minimize experimental errors, the same worker operated all the plots throughout the experiment.

The results were evaluated through the analyses of variance, determined by the F test. Means were compared by the Tukey test with significance of 5\%. 


\section{RESULTS AND DISCUSSION}

A significant effect was found for spacing, pruning regime and cultivar over the number of fruits per plant and per area unit, total and commercial yield. Besides, an interaction between cultivar and pruning regime over the number of fruits per cluster was also shown. Regarding fruit quality, pruning regime and cultivar effect were observed over the longitudinal diameter of the fruits, spacing over the average mass and a significant cultivar and pruning regime effect over the transversal diameter and fruit mass.

The largest spacing of $0.8 \times 1.5 \mathrm{~m}$ resulted in a higher number of fruits per cluster and per plant, followed by the spacings of $0.6 \times 1.5 \mathrm{~m}$ and $0.4 \times 1.5$ $\mathrm{m}$, though in a lower number of clusters and fruits per area unit $\left(\mathrm{m}^{-2}\right)$ (Table 1$)$ due to the lower number of plants per $\mathrm{m}^{2}$. Likewise, the wider spacings $(0.8 \mathrm{x}$ $1.5 \mathrm{~m}$ and $0.6 \times 1.5 \mathrm{~m}$ ) resulted in higher total and commercial productions per plant than the narrowest spacing, $0.4 \mathrm{x}$ $1.5 \mathrm{~m}$, which became outstanding for presenting, with the spacing $0.6 \times 1.5$, higher yield per area $\left(\mathrm{t} \mathrm{ha}^{-1}\right)$ (Table 1$)$.

The increase in the total number of fruits per area and the increase in the plant population, with $0.4 \times 1.5 \mathrm{~m}$ spacing, was responsible for the yield increase, compensating for the reduction in the fruit mass (Table 2). In the treatment with intermediary population, i.e. $0.6 \times 1.5 \mathrm{~m}$, the lower total number of fruits compared to the treatment of 0.4 x $1.5 \mathrm{~m}$ was compensated by a higher fruit mass, resulting in an equivalent yield to the previous treatment (Tables 1 and 2). Apparently, the gain in yield per area with the increase in the plants' population was mainly due to the increase in the total number of fruits, whereas in the intermediary spacing, such effect was compensated by the bigger fruit mass and in the larger spacing, $0.8 \times 1.5 \mathrm{~m}$, the mass increase was not sufficient due to the limitation in the characteristics of the genotypes used and the adopted management. These results are in accordance with Streck et al. (1998), who reported quantitative gains in the production of the tomato group Santa Cruz, with an increase in the plants' density, once competition for radiation does not occur. These results also are in accordance with the ones of Machado et al. (2003b), who reported an increase in the fruits' number, with the increase in the planting density for the cherry tomato group. Campos et al. (1987) also reported, for the tomato group Santa Cruz, a compensation for the reduction in number and the fruits' fresh mass per plant, with the increase of the plants' density. The increase in the production per plant in the largest spacings $(0.6 \times 1.5 \mathrm{~m}$ and $0.8 \times 1.5 \mathrm{~m})$ is due to the increase in the number of fruits per cluster, once there was no spacing effect over the number of clusters per plant in any of the spacings tested.

The tomato plant's yield is directly related to the number of plants per area unit, number of harvested fruits per plant and the average fruit mass (Streck et al., 1998), presenting a positive relation between the density and increase in production, even though with a reduction in size and average fruit mass (Streck et al., 1996; Streck et al., 1998), whose effect may vary depending on the cultivar, time of the year and other management practices.

Concerning the pruning regime, the treatment with a single branch per plant presented a higher number of fruits per cluster than the pruning regimes with two branches or at free growth in which all the branches were kept. However, the reduction in number of fruits per cluster in the two previous treatments was proportionally compensated by the increase in the number of clusters per plant, with a significantly bigger number of fruits per plant and area unit in the free growth treatment followed by the one with two branches (Table 1). These results are in accordance with the ones of Charlo et al. (2004) and Postali et al. (2004), who also verified, for the cherry tomato, a larger number of fruits per plant with the increase in the number of branches pruned per plant. This positive relation between the number of branches and number of clusters and fruits per plant is explained by the fact that the tomato plant presents a certain peculiarity in its form of development. After the first occurrence of inflorescence on the plant branches, the next will occur above the third leaf in the same branch and so forth (Alvarenga, 2004). Hence, the higher the number of branches the greater is the possibility for the plant to produce inflorescences thus forming new clusters.

The number of fruits per cluster, however, was affected by the interaction cultivar $\mathrm{x}$ pruning regime, presenting stronger effects in the pruning regime for 'Super Sweet', which, as a whole, presented bigger number of fruits per cluster than 'Perinha Água Branca'(Table 3). The cultivar Super Sweet was outstanding for its higher number of fruits per cluster, except in the free growth treatment, higher number of fruits per plant and per area unit and, consequently, higher fruit yield per plant and per area (Table 3).

The effect of interaction cultivar $\mathrm{x}$ pruning regime over the number of fruits per cluster did not result in a similar effect concerning the number and fruits' mass per plant and per area due to the component number of clusters per plant and per area unit. The treatment with vertical pruning of a single branch per plant presented lower fruit yield per plant and per total and commercial area than the treatments with vertical pruning of two branches per plant and at free growth, which did not differ among them (Table 1). The smaller number of clusters and fruits produced by the plants with one branch explains the lower production per plant and yield observed in this treatment, which means that the yield potential of the plant was harmed by the lower number of branches, indicating that the gains in the cherry tomato's yield can be obtained with the pruning of higher number of branches per plant. Such results are in accordance with the ones of Postali et al (2004) with two cherry tomato cultivars in a hydroponic regime. For cultivar Pepe they reported an increase in production per plant of around $23 \%$ with the pruning of two or four branches compared to the pruning with a single branch as well as in cultivar Super Sweet, an increase in the production per plant of 6 to $21 \%$ with pruning of two and four branches, respectively, compared to the pruning with a single branch. Nevertheless, the results differ from the ones of Charlo et al. (2004), who did not observe 
Table 1. Effect of row spacing and pruning regimes on individual yields $\left(\mathrm{kg} \mathrm{plant}^{-1}\right)$, total, marketable and non marketable yields $\left(\mathrm{t}\right.$ ha $\left.{ }^{-1}\right)$ of cherry tomatoes grown in the spring-summer experiment (número de frutos por planta, por unidade de área $\left(\mathrm{m}^{2}\right)$ e por cacho e produtividade total e de frutos com padrão comercial, por planta $\left(\mathrm{kg}\right.$ planta $\left.{ }^{-1}\right)$ e por área $\left(\mathrm{t} \mathrm{ha}{ }^{-1}\right)$, em função do espaçamento e do sistema de condução de tomate cereja em cultivo no período de primavera-verão, sob manejo orgânico). Seropédica, UFRRJ, 2004.

\begin{tabular}{|c|c|c|c|c|c|c|c|}
\hline \multirow{2}{*}{ Spacing $(\mathrm{m})$} & \multirow{2}{*}{$\mathbf{N}^{0}$ fruits/plant } & \multirow{2}{*}{$\mathbf{N}^{0}$ fruits $/ \mathbf{m}^{2}$} & \multirow{2}{*}{$\mathbf{N}^{0}$ fruits/cluster } & \multicolumn{2}{|c|}{ Total yield } & \multicolumn{2}{|c|}{ Commercial yield } \\
\hline & & & & kg/plant & t/ha & kg/plant & t/ha \\
\hline $0.4 \times 1.5$ & $67.9 \mathrm{c}$ & $113.2 \mathrm{a}$ & $7.4 b$ & $0.75 b^{1}$ & $12.46 \mathrm{a}^{1}$ & $0.57 \mathrm{~b}$ & $9.55 \mathrm{a}^{1}$ \\
\hline $0.6 \times 1.5$ & $105.8 \mathrm{~b}$ & $117.5 b$ & $9.3 \mathrm{ab}$ & $1.08 \mathrm{a}$ & $11.95 \mathrm{a}$ & $0.79 \mathrm{a}$ & $8.80 \mathrm{a}$ \\
\hline $0.8 \times 1.5$ & $111.4 \mathrm{a}$ & $2.9 \mathrm{c}$ & $10.4 \mathrm{a}$ & $0.99 \mathrm{a}$ & $8.23 b$ & $0.72 \mathrm{ab}$ & $6.02 \mathrm{~b}$ \\
\hline \multicolumn{8}{|l|}{ Pruning regime } \\
\hline two branches/plant & $78.9 \mathrm{c}$ & $90.5 \mathrm{c}$ & $11.1 \mathrm{a}$ & $0.77 b^{1}$ & $9.02 b^{1}$ & $0.58 b$ & $6.83 b$ \\
\hline one branch/plant & $95.8 \mathrm{~b}$ & $108.9 \mathrm{~b}$ & $8.4 \mathrm{~b}$ & $1.01 \mathrm{a}$ & $11.63 \mathrm{a}$ & $0.80 \mathrm{a}$ & $9.13 \mathrm{a}$ \\
\hline free growth & $110.4 \mathrm{a}$ & $124.2 \mathrm{a}$ & $7.3 \mathrm{~b}$ & $1.04 \mathrm{a}$ & $11.99 \mathrm{a}$ & $0.72 \mathrm{ab}$ & $8.41 \mathrm{ab}$ \\
\hline $\mathrm{CV}(\%)$ & 15.49 & 18.39 & 25.89 & 24.7 & 27.9 & 26.5 & 28.9 \\
\hline
\end{tabular}

${ }^{1}$ Means followed by the same letter are not significantly different $(\mathrm{p}<0.05 \%)$ by Tukey test (médias seguidas da mesma letra não diferem significativamente entre si ao nível de $5 \%$ de probabilidade pelo teste de Tukey).

Table 2. Effects of row spacing on average fruit mass, pruning regimes and cultivar on longitudinal fruit diameter and interaction between pruning regimes $\mathrm{x}$ cultivar on longitudinal fruit diameter of cherry tomatoes grown in the spring-summer experiment (massa média em função do espaçamento, diâmetro longitudinal em função do sistema de condução e de cultivar, diâmetro transversal e massa média em função da interação cultivar e sistema de condução em frutos de tomate cereja produzidos no período de primavera-verão sob manejo orgânico). Seropédica, UFRRJ, 2004.

\begin{tabular}{lc}
\hline Spacing $(\mathbf{m})$ & Average fruit mass $(\mathbf{g})$ \\
\hline $0.6 \times 1.5$ & $8.21 \mathrm{a}$ \\
$0.8 \times 1.5$ & $7.30 \mathrm{ab}$ \\
$0.4 \times 1.5$ & $6.56 \mathrm{~b}$ \\
\hline Pruning regime & Longitudinal fruit diameter $(\mathbf{c m})$ \\
\hline one branch/plant & $3.00 \mathrm{a}^{1}$ \\
two branches/plant & $2.87 \mathrm{~b}$ \\
free growth & $2.70 \mathrm{c}$ \\
\hline
\end{tabular}

\begin{tabular}{|c|c|c|c|}
\hline Cultivar & & & \\
\hline Perinha & & $3.31 \mathrm{a}^{1}$ & \\
\hline Super Sweet & & $2.40 \mathrm{~b}$ & \\
\hline \multirow{2}{*}{ Cultivar } & \multicolumn{3}{|c|}{ Transversal fruit diameter $(\mathrm{cm})$} \\
\hline & One branch/plant & Two branches/plant & Free growth \\
\hline Perinha & $2.65 \mathrm{Aa}^{1}$ & $2.58 \mathrm{Aa}$ & $2.54 \mathrm{Aa}$ \\
\hline Super Sweet & $2.65 \mathrm{Aa}$ & $2.56 \mathrm{Aa}$ & $2.36 \mathrm{Bb}$ \\
\hline CV $(\%)$ & \multicolumn{3}{|c|}{9.88} \\
\hline
\end{tabular}

\begin{tabular}{lccc}
\hline & \multicolumn{3}{c}{ Average fruit mass (g) } \\
\cline { 2 - 4 } & One branch/plant & Two branches/plant & Free growth \\
\hline Perinha & $7.46 \mathrm{Aa}$ & $8.50 \mathrm{Aa}$ & $5.86 \mathrm{Bb}$ \\
Super-Sweet & $7.15 \mathrm{Aa}$ & $7.91 \mathrm{Aa}$ & $7.26 \mathrm{Aa}$ \\
\hline $\mathrm{CV}(\%)$ & \multicolumn{4}{c}{17.22} \\
\hline
\end{tabular}

${ }^{1}$ Means followed by the same uppercase letter on the line and by lowercase letters on the column are not significantly different $(\mathrm{p}<0.05 \%$ by Tukey test) (médias seguidas da mesma letra não diferem significativamente entre si ao nível de $5 \%$ de probabilidade pelo teste de Tukey).

significant differences in the fruit production per plant when they were pruned with one or two branches, even having presented production per plant and total and commercial fruit yield similar to the vertical pruning of two branches, resulted in a higher quantity of fruits with damage, equivalent to $31 \%$ of the fruits produced, whereas in the other two treatments this value was 24.5 and $21.7 \%$. This higher loss in the pruning regime at free growth is related to its own formation of a microclimate, caused by a higher humidity accumulation due to a lower air circulation and a higher contact of the fruits with the soil, which favored phytosanitary problems leading to a higher leaf loss due to the exposure of their fruits to the sun rays and the attack of the corn earworm (Helicoverpa zeae Boddie, 1850, Lepidoptera: Noctuidae), respectively. On the other hand, despite the gain in number of fruits and yield due to the pruning regime and the increase in the number of branches per plant from one to two with the maintenance of all branches through free growth regime, there was a reduction in the fruits' size due to a reduction in the longitudinal diameter, independent of the cultivar (Tables 1 and 2). We also observed a pruning effect over the transversal diameter of fruits in 'Super Sweet' and over the fruits' mass in 'Perinha Água Branca', with lower means in the regime at free growth (Table 2). The 'Perinha Água Branca' cultivar presented a bigger longitudinal diameter than 'Super Sweet', for producing oval fruits, compared to 'Super Sweet', which produced round fruits (Table 2).

Despite the significant spacing 
Table 3. Effect of pruning regimes and cultivars on the number of fruits per plant, number of fruits per square meter and total yield of marketable cherry tomatoes grown in the spring-summer experiment (número de frutos por cacho, por planta e por unidade de área e produtividade total e de frutos com padrão comercial, em função do sistema de condução e de cultivar de tomate cereja, em cultivo no período de primavera-verão, sob manejo orgânico). Seropédica, UFRRJ, 2004.

\begin{tabular}{|c|c|c|c|c|c|c|c|c|c|}
\hline \multirow[b]{2}{*}{ Cultivar } & \multicolumn{3}{|c|}{$\mathbf{N}^{0}$ fruits/cluster } & \multirow{2}{*}{$\begin{array}{c}\mathrm{N}^{0} \\
\text { fruits/ } \\
\text { plant }\end{array}$} & \multirow{2}{*}{$\begin{array}{c}\mathrm{N}^{0} \\
\text { fruits/ } \\
\mathbf{m}^{2}\end{array}$} & \multicolumn{2}{|c|}{ Total yield } & \multicolumn{2}{|c|}{ Commercial yield } \\
\hline & $\begin{array}{c}\text { One branch/ } \\
\text { plant }\end{array}$ & $\begin{array}{c}\text { Two branches/ } \\
\text { plant }\end{array}$ & $\begin{array}{c}\text { Free } \\
\text { growth }\end{array}$ & & & $\begin{array}{l}\mathbf{k g} / \\
\text { plant }\end{array}$ & t/ha & kg/plant & t/ha \\
\hline Perinha & $9.3 \mathrm{Ab}^{1}$ & $6.8 \mathrm{Bb}$ & 7.07ABa & $88.1 b^{1}$ & $100.4 \mathrm{~b}$ & $0.84 b^{1}$ & $9.7 \mathrm{~b}^{1}$ & $0.63 b$ & $7.37 b$ \\
\hline Super-sweet & $13.1 \mathrm{Aa}$ & $10.1 \mathrm{Ba}$ & $7.64 \mathrm{Ca}$ & $102.0 \mathrm{a}$ & $115.3 \mathrm{a}$ & $1.04 \mathrm{a}$ & $11.9 \mathrm{a}$ & $0.77 \mathrm{a}$ & $8.87 \mathrm{a}$ \\
\hline CV (\%) & & 25.89 & & 15.49 & 18.39 & 24.7 & 27.9 & 26.5 & 28.9 \\
\hline
\end{tabular}

${ }^{1}$ Means followed by the same uppercase letter on the line and by lowercase letters on the column are not significantly different $(\mathrm{p}<0.05 \%$ by Tukey test) (médias seguidas da mesma letra, maiúscula na linha e minúscula na coluna, não diferem significativamente entre si ao nível de $5 \%$ de probabilidade pelo teste de Tukey).

Table 4. Effect of the interaction between pruning regimes and row spacing on the costs of cherry tomato pruning operations during the spring-summer experiment, and the effect of cultivar on the labor costs (day/man/ha) during the spring-summer experiments (custo em reais para a realização da desbrota das hastes em plantas de tomate do grupo cereja em função da interação entre sistema de condução e espaçamento, em cultivo no período de primavera-verão sob manejo orgânico). Seropédica, UFRRJ, 2004.

\begin{tabular}{lccc}
\hline \multirow{2}{*}{ Pruning regime } & \multicolumn{3}{c}{ Costs (reais/ha) } \\
\cline { 2 - 4 } & $\mathbf{0 . 4 \times 1 . 5 ~} \mathbf{~}$ & $\mathbf{0 . 6} \times \mathbf{1 . 5} \mathbf{~ m}$ & $\mathbf{0 . 8} \times \mathbf{1 . 5} \mathbf{~ m}$ \\
\hline one branch/plant & $1,886.61 \mathrm{Ab}^{1}$ & $1,358.67 \mathrm{Bb}$ & $1,162.92 \mathrm{Bb}$ \\
two branches/plant & $2,593.70 \mathrm{Aa}$ & $2,252.27 \mathrm{Aa}$ & $1,822.60 \mathrm{Ba}$ \\
free growth & $0.00 \mathrm{Ac}$ & $0.00 \mathrm{Ac}$ & $0.00 \mathrm{Ac}$ \\
\hline $\mathrm{CV}(\%)$ & & 17.43
\end{tabular}

${ }^{1}$ Means followed by the same uppercase letter on the line and by lowercase letters on the column are not significantly different ( $\mathrm{p}<0.05 \%$ by Tukey test) (médias seguidas da mesma letra não diferem significativamente entre si ao nível de $5 \%$ de probabilidade pelo teste de Tukey; *Custo calculado tendo como base jornada diária de 8,0 h de trabalho e R $\$ 20,00$ o custo da diária).

and the cultivar interaction pruning regime over the fruit mass, this one, in general, did not present great variations in commercial terms, keeping the average of 5.86 to $8.50 \mathrm{~g}$, which corresponds to the same class according to the classification system proposed by Fernandes et al. (2007), for tomato fruits from the cherry tomato group, which have small size with a 5 to $10 \mathrm{~g}$ and 20 to $25 \mathrm{~cm}$ mass of transversal diameter.

Comparing the cultivar SuperSweet to the 'Perinha Água Branca', the former presented higher number of fruits per plant and per area unit of total and commercial fruits (Table 2). Although the production of damaged fruits was higher in 'Super-Sweet' than in 'Perinha Água Branca', in percentage terms, both cultivars were the same, with approximately $25 \%$. Machado et al. (2003a) reported a production of $2.88 \mathrm{~kg}$ per plant in 'Super Sweet', pruned in the conventional regime, in the spacing and labor cost to carry out the pruning, regarding the number of day $\operatorname{man}^{-1}$ spent in an area equivalent to one hectare and, therefore, in the cost in R\$ ("reais"). There was no cultivar effect. The plants in the free growth regime did not go through pruning and, thus did not have any costs. In the other cases, for the plants pruned with one branch as well as for those pruned with two branches, as the spacing between plants was enlarged it reduced the labor cost due to the smaller plants' population (Table 4). In the treatments whose plants were pruned with one or two branches, we verified an additional labor cost of approximately 17 to $18 \%$ and of 62 to $42 \%$, respectively, when the spacing of $0.8 \times 1.5 \mathrm{~m}$ was reduced to $0.6 \times 1.5$ and from $0.8 \times 1.5$ to $0.4 \times$ $1.5 \mathrm{~m}$, respectively. Nevertheless, the increase in the commercial fruit yield due to the reduction in spacings from $0.8 \times 1.5$ to $0.6 \times 1.5 \mathrm{~m}$ and $0.4 \times 1.5$ $\mathrm{m}$, considering the average between the two pruning regimes, was 44.5 and $58.6 \%$, respectively. The pruning regime of the plants with two branches compared to the one with a single branch presented a higher labor cost of $38.2,66.1$ and $56.8 \%$ in the treatments combining spacings of $0.4 \times 1.5 \mathrm{~m}$, $0.6 \times 1.5$ and $0.8 \times 1.5 \mathrm{~m}$, respectively, with an average yield increase of $33.6 \%$ (Tables 1 and 4). Such results indicate that, when choosing the pruning regime and defining the spacing to be used, the producer must consider several factors, among which, the availability and labor cost in the region, the size of the area available for planting and the price of the tomato box. 
Based on these results, it can be concluded that the spacing of 0.6 $\mathrm{m}$ between the plants is the most recommendable for the cherry tomato production in organic regime and that the free growth crop may be viable in this period of the year. However, it presents higher loss due to a higher incidence of damaged fruits, like the ones caused by the fruits' corn earworm (H. zeae) and scalding. In the free growth regime, despite the higher loss, it did not necessarily compromise the commercial fruit yield and there was lower labor cost with the production. Nevertheless, in order to choose a production regime at free growth or vertical pruning with the elimination of lateral sprouts and limited number of branches per plant, we must consider the climatic conditions in the region, the labor cost and the price of the tomato box.

\section{ACKNOWLEDGEMENTS}

To CAPES, for granting the Master course scholarship and to UFRRJ, for the structure and support to carry out this study.

\section{REFERENCES}

AKIBA F; CARMO MGF; RIBEIRO RLD. 1999. As doenças infecciosas das lavouras dentro de uma visão agroecológica. Ação Ambiental 5: 30-33.

ALVARENGA MAR. 2004. Tomate: produção em campo, em casa-de-vegetação e em hidroponia. Lavras: Editora UFLA, $400 \mathrm{p}$.

BOFF P; FONTES PCR; VALE FX; ZAMBOLIM L. 1992. Controle da mancha de estenfílio e da pinta-preta do tomateiro em função do sistema de condução. Horticultura brasileira 10: 25-27.

CAMPOS JP; BELFORD CC; GALVÃO JD; FONTES PCR. 1987. Efeito da poda da haste e da população de plantas sobre a produção do tomateiro. Revista Ceres 34: 198-208.

CARVALHO, LA; TESSARIOLI NETO J. 2005. Produtividade de tomate em ambiente protegido, em função do espaçamento e número de ramos por planta. Horticultura Brasileira 23: 986-989.

CHARLO HCO; CASTOLDI R; CONTI PL; FARIA AU; BRAZ LT; FERNANDES C. 2004. Desempenho de mini tomate em casa de vegetação, conduzido em diferentes espaçamentos e poda. In: CONGRESSO BRASILEIRO DE OLERICULTURA, 44. 2004, Campo Grande. Campo Grande: SOB (CD-ROM).

EMPASC 1991. Sistema de produção para tomate para o Estado de Santa Catarina. Florianópolis: EMPASC/EMATER. 75 p. (Sistemas de Produção n. 18).

FERNANDES C; CORÁ JE; BRAZ LT. 2007. Classificação de tomate-cereja em função do tamanho e peso dos frutos. Horticultura Brasileira 25: 275-278.

FILGUEIRA FAR 2003. Novo manual de olericultura: agrotecnologia moderna na produção e comercialização de hortaliças. Viçosa: UFV. 402 p.

HO LC. 1999. The physiological basis for improving tomato fruit quality. Acta Horticulturae 487: 33-40.

LÉDO FJS; CAMPOS JP; FONTES PCR; GOMES JA; REIS FP. 1995. Comportamento de seis cultivares de tomate de crescimento determinado, sob três sistemas de condução da planta, na produção de frutos para consumo in natura. Revista Ceres 42: 218-224.

MACHADO JO; BRAZ LT; GRILLI GVG. 2003a. Caracterização dos frutos de cultivares de tomateiro tipo cereja cultivados em diferentes espaçamentos. In: CONGRESSO BRASILEIRO DE OLERICULTURA, 43. 2003, Recife. Recife: SOB (CD-ROM).

MACHADO JO; BRAZ LT; GRILLI GVG. 2003b. Desempenho de produção de cultivares de tomateiro tipo cereja em diferentes espaçamentos. In: CONGRESSO
BRASILEIRO DE OLERICULTURA, 43. 2003, Recife. Recife: SOB (CD-ROM).

MARIM BG; SILVA DJH; GUIMARÃES MA; BELFORT G. 2005. Sistemas de tutoramento e condução do tomateiro visando produção de frutos para consumo in natura. Horticultura Brasileira 23: 951-955.

OLIVEIRA VR; CAMPOS JP; FONTES PCR; REIS FP. 1995. Efeito do número de hastes por planta e poda apical na produção classificada de frutos de tomateiro. Ciência e Prática 19: 414-419.

POSTALI GB; SILVA EC; MACIEL GM. 2004. Produção de híbridos comerciais de tomateiros do grupo cereja cultivados no sistema hidropônico com diferentes números de hastes. In: CONGRESSO BRASILEIRO DE OLERICULTURA, 44. 2004, Campo Grande. Campo Grande: SOB (CD-ROM).

RUGHOO M; GOVINDEN N. 1999. Response of three salad tomato varieties to staking and pruning. Revue Agricole et Sucriere 78: 26-34.

SANTOS HS; PERIN WH; TITATO LG; VIDA JB; CALlEGARI O. 1999. Avaliação de sistemas de condução em relação à severidade de doenças e à produção do tomateiro. Acta Scientiarum 21: 453-457.

SOUZA JL; RESENDE P. 2003. Manual de Horticultura Orgânica. Viçosa: Aprenda Fácil. 564p.

STRECK NA; BURIOL GA; SCHNEIDER FM. 1996. Efeito da densidade de plantas sobre a produtividade do tomateiro cultivado em estufa de plástico. Pesquisa Agropecuária Brasileira 31: 105-102.

STRECK NA; BURIOL GA; ANDRIOLO JL; SANDRI MA. 1998. Influência da densidade de plantas e da poda apical drástica na produtividade do tomateiro em estufa de plástico. Pesquisa Agropecuária Brasileira 33: 1105-1112.

WAMSER AF; MUELLER S; BECKER WF; SANTOS JP. 2007. Produção do tomateiro em função dos sistemas de condução de plantas. Horticultura Brasileira 25: 238-243.

WAMSER AF; BECKER WF; SANTOS JP; MUELLER S. 2008. Influência do sistema de condução do tomateiro sobre a incidência de doenças e insetos-praga. Horticultura Brasileira 26: 180-185. 